Varnai, Paul. "Körner, András. 2013. Egy vonakodó zsidó ('A Reluctant Jew'). Budapest: 2B Kulturális és Müvészeti Alapítvány."Hungarian Cultural Studies. e-Journal of the American Hungarian Educators Association, Volume 8 (2015): http://ahea.pitt.edu DOI: 10.5195/ahea.2015.208

\title{
Körner, András. 2013. Egy vonakodó zsidó ('A Reluctant Jew'). Budapest: 2B Kulturális és Müvészeti Alapítvány.
}

\section{Reviewed by Paul Varnai, Carleton University, Ottawa}

The title of this memoir itself is telling. Because of age-old anti-Jewish prejudices and persecution it is not at all surprising that a Jew might be reluctant to endorse his or her Jewish identity. The Budapest born (1940) András Körner has by now lived in New York, a city where he feels entirely at home, for forty years. In his autobiographical essays and stories he discusses his ambivalence about his Jewish identity, a stance characterized by a lifelong battle with his Jewishness, which eventually led him to a full acceptance of and interest in Jewish traditions and culture. Moreover, after his retirement as an architect Körner has become a historian of Hungarian Jewish everyday life (for an engaging profile on Körner's life and publications, see the blog by historian Holly Case at: www.ecepastandpresent.blogspot.hu/2014/05/extendedrpofile-andras-korner.html ).

András was born into an assimilated middle-class Jewish family in Budapest. Having experienced the horrors of the Holocaust, many Hungarian Jewish parents preferred not to tell their children who were born after the war about their origin in order to spare them possible discrimination or persecution. (There might have been such cases even prior to World War II, but certainly few outside of Budapest, as in towns and villages people's religious affiliation was common knowledge, and merely the foreign sounding last names of Jews would easily give them away. Besides, after the anti-Jewish laws of 1938 and 1939 were implemented, it would have been hard to conceal one's origin.) When in 1944 András' mother was taken away for forced labor and possibly potential annihilation, András was already four years old but much too young to have an adult understanding of what was happening to him. Hence, he is uncertain about whether he belongs to the first or the second generation of Holocaust victims and, in fact, he regards himself as a borderline case. What he knows about the year 1944-45 is partly what he remembers and partly what he heard later from his family, with the two perspectives tending to merge in his memory. Notwithstanding the time he spent in the Budapest ghetto and the so-called Yellow Star House, he wonders if he is indeed a survivor, since he was never in a lifethreatening situation (on this in-between generation and consciousness see: Susan Rubin Suleiman, "The 1.5 generation." American Imago 59.3 [2002], 277-295).

Following their liberation from the camp and the ghetto and becoming, at long last, equal members of society, the majority of survivors tried to forget the past and looked toward the future, hoping for a life without discrimination and with equal opportunities as the rest of Hungarian society. The majority of Hungary's post World War II Jewry remained Jews only in private, to the extent that the word "Jew" was seldom heard even within the family. András' parents were typical middle-class (bourgeois) people, living in a district traditionally populated by Jewish businessmen, lawyers, doctors, and artists. This segment of Hungarian Jews was very assimilated, often called "non-Jewish Jews" and looking down upon the decreasing number of Orthodox Jews, who in Polish and Hungarian were traditionally called Galician (meaning

(cc) $\mathrm{Br}$

ULIS D-Serle 
Varnai, Paul. "Körner, András. 2013. Egy vonakodó zsidó ('A Reluctant Jew'). Budapest: 2B Kulturális és Müvészeti Alapítvány."Hungarian Cultural Studies. e-Journal of the American Hungarian Educators Association, Volume 8 (2015): http://ahea.pitt.edu DOI: 10.5195/ahea.2015.208

backwards Eastern-European Jews). The "Jewish" approach and behaviour of these Jews were resented by the circle of András's family, and András' mother recalls that even in the camp they were a different sort: dirty, wild, agressive, and Yiddish speaking. Myself, having been deported to camps as a child, I recall a similar resentment towards these "Eastern" Jews by Hungarian middle class Jews. I suspect that the contempt might have been mutual. Many of the Holocaust survivors among these Jews left Hungary after the Communist takeover in 1948-9, whereas those who remained in the country continued practicing their faith and lifestyle. On another note, András could not help noticing that, on the one hand, his parents socialized exclusively with Jews of their own class and, on the other, they celebrated Christmas and tried to look Hungarian in their external appearance, which was, in fact, a typical schizophrenic disposition.

One of the central issues in this book is the son's relationship with his mother. The mother was an agressive, often violent person, who went as far as punishing her children physically and hardly showing them any affection. She told them practically nothing about her deportation, nor did she ask her son about what he went through in her absence. Many years following his emigration or rather escape to New York, András decided to finally confront his mother asking her to tell him about her life, their family background, their Jewish family history and, first and foremost, about her experinces in the camp. He did that to learn about her life and the family's past, but also for the hope that their distant, icy relationship might improve somewhat. To his surprise, his mother readily opened up and easily and rather joyfully agreed to talk to him. Thus, over several years, on his annual visits to Budapest András taped his mother's hitherto untold stories about the traditional Jewish life of her ancestors, her parents and grandparents, as well as about the gruesome months she spent in the camp. He ultimately ended up with a three-hundred page oral history memoir. It was a major shock for András to learn that, in her desparate attempt to survive, his mother had volunteered to become a Kapo, a privileged position in the camp empowering her to rule over her campmates, including the right to physically punish them. To what degree she used or misused her authority over her campmates, she never divulged to him, and while intellectually and morally András judged her, ultimately emotionally he could not. In fact, he rather pitied and absolved her of her dubious doings. He also asked himself the question of what he might have done in her place. Lastly, seeing his aging and ailing mother opening up to him, András felt that, after all those years, her confessions finally brought them closer to each other.

Throughout the book András reflects on his own gradual mental, emotional, and intellectual development. Being fully aware of what his family had gone through during the war and in the following years, András has tried to keep his distance from his Jewish classmates. Even as a schoolboy he had many Christian friends; in fact, all his girlfriends in Hungary were Christian. At the same time he had an early interest in Jewish culture but only a very very limited access to it prior to his emigration. At the age of twenty six he left Hungary for the United States, together with an American born girlfriend of German Jewish descent whom he had met in Austria and eventually married in Germany, before the couple reached New York. In America, witnessing the prevailing attitude of tolerance towards religious and ethnic minorities that he had never experienced before, and having an easy access to Jewish literature and culture, András became fully absorbed by them. Both he and his wife came from assimilated, non-religious families and both kept some of their assimilated European Jewish traditions in America, such as the celebration of Christmas along with Hannukah. 
Varnai, Paul. "Körner, András. 2013. Egy vonakodó zsidó ('A Reluctant Jew'). Budapest: 2B Kulturális és Müvészeti Alapítvány."Hungarian Cultural Studies. e-Journal of the American Hungarian Educators Association, Volume 8 (2015): http://ahea.pitt.edu DOI: 10.5195/ahea.2015.208

Nonetheless, it was his new life in America that helped András to fully accept the Jewish cultural heritage of his distant ancestors and to feel part of Jewish culture and traditions. In fact, after retiring as an architect, he began to publish books on his Jewish cultural heritage. In 2003 he published a book on Hungarian Jewish culinary tradition titled A Taste of the Past - The Daily Life and Cooking of a Nineteenth-Century Hungarian Jewish Homemaker (UP of New England; published in Hungarian in 2005 as Kostoló a múltbol. Budapest: Vince Kiadó), based on the handwritten recipe book of Ashkenazi Hungarian cooking of his great-grandmother, Theresa (Riza) Baruch (1851-1938), adapted to modern measurements and ingredients. Although the volume was based on a cache of letters, recipes, and personal artifacts of his great-grandmother, it was also complemented by his mother's eyewitness testimony of her cooking, as she had been partially raised by her grandmother (on this cookbook see further the review by Ivan Sanders: "An Artist, a Robber, a Cook," The Hungarian Quarterly 46.179: 146-152). In 2013 Körner published in Hungarian Hogyan éltek? A magyar zsidók hétköznapi élete 1867-1940 ('How Did They Live? The Everyday Life of Hungarian Jews in 1867-1940.' Budapest: Corvina), where with the aid of contemporary photographs, including those from his own family, he depicts the second half of the nineteenth century and the first half of the twentieth century Jewish everyday life, a life that essentially disappeared with the Holocaust. In that book he says that even more than grieving for all the famous people who were annihilated he grieves for the nameless shoemakers, country doctors, and for his mother's uncle who had an inn in Léva, from where he (András) still has a wonderful recipe for date torte, which he still prepares.

This is a readable and fascinating autobiographical book, probably one of the best in Hungarian on the subject. In analyzing himself, his family and the society in which he grew up Körner makes his "conversion" back into Jewishness credible. Last but not least, his book demonstrates the dilemmas of Hungarian and, indeed, many European Jews about living as a minority in often hostile societies. As said, to be a reluctant Jew is not a rare situation in the diaspora; András Körner's stories bring to mind Balázs Körmendi's remarkable book, Zsidó gyónás ('Jewish Confession,'), which was written in 1942-43 and first published in 1946 (and recntly, in 2006, reprinted by Argumentum Press at Budapest). That author, whose real name was Dr. István (Shlomo) Kulcsár, practised psychiatry in Hungary and, following his immigration to Palestine after the war, he acted as a psychiatry expert at the Eichmann trial. Excessively introspective, Körmendi, who was some twenty-five years older than Körner, analyzes his long period of ambivalence about his identity in the interwar period and his vain efforts to belong to the non-Jewish mainstream. Regular Jew-beating at the universities, virulent antisemitism and formal and informal discrimination all produced a somewhat schizophrenic mentality in many Jews, especially among the intellectuals. The long vacillation between assimilation and emulation of Christian mentality and values as well as the gradual acceptance of one's Jewishness are the subject of Körmendi's book just as they are at the center of Körner's book. Sorrowfully, these problems haven't disappeared: Jews in many countries of the diaspora are still exposed to external threats and prejudices as to inner doubts and uncertainty about their identity, and the dilemma of whether to stay in their native countries or leave and where to is an ongoing preoccupation for many of Jews to this day 